\title{
An Observational Clinical Study to Evaluate The Efficacy of Kutaja Siddha Haritaki Churna and Vyadhignadi taila after virechana karma in the Management of Ekakushta vis-a-vis Chronic Plaque Psoriasis
}

\author{
Research Article
}

\author{
Kalpana Rao ${ }^{1^{*}}$, Mythrey R C ${ }^{2}$ \\ 1. PG Scholar, 2. Professor, \\ Department of Post Graduate studies in Kayachikitsa. GAMC,Mysuru
}

\begin{abstract}
Psoriasis is chronic disorder which is commonly encountered in day to day's clinical practices. It is a relapsing \& remitting disease of skin causing social isolation, cosmetic \& psychological embarrassment as well as difficulties in leading social life. Even though it can be considered as an autoimmune disorder affecting skin, it cannot always be treated as somatic lesion, it is infact multifactorial in origin \& conditioned by various constitutional \& environmental factors. Due to altered life style, lack of physical exercise, unhygienic, mental stress \& over eating skin diseases are commonly observed. Although Eka-kushta is a rakta pradoshaja, vata-kaha pradhana tridoshaja kshudra kushta, it bears a great resemblance with psoriasis. The current treatment modalities have their own limitations \& the drugs have considerable side effects when used for a longer period.

Therefore, there is a need for more comprehensive, economical \& safe medications and methods of management of psoriasis. Hence a clinical study was conducted on 20 patients assigned to evaluate the Efficacy of Kutaja Siddha Haritaki Churna and Vyadhignadi taila after virechana karma in the Management of Ekakushta visa-vis Chronic Plaque Psoriasis. At the end of 30 days of treatment involving shodhana (virechana) followed by shamanoushadhis and external medication resulted in significant improvement in the overall effect of therapy in reducing itching scaling, erythema and thickness .So it can be inferred that ayurvedic management of chronic plaque psoriasis with above mentioned medicines can be effectively used.
\end{abstract}

Keywords: Ekakushta, Chronic plaque psoriasis, Kutaja siddha haritaki choorna, Vydhignaditaila .

\section{Introduction}

In Ayurvedic science almost all the skin diseases are explained under kushta rogadhikara and are classified under seven Mahakushta and eleven kshudra kushta. All types of kushta are considered as raktapradoshaja vikara.(1) Ekakushta is one among eleven varieties of kshudra kushta. Further ekakushta is stated to be tridoshaja with the predominance of kaphavata doshas.(2) It is characterised by Aswedanam, Mahavastu, Matsyashakalavat twacha .(3) which bears a greater resemblance with Chronic plaque psoriasis. Psoriasis is a chronic autoimmune disease, which appears as red, scaly patches on the skin(4) known as chronic psoriatic plaques. These plaques give it a silvery-white appearance. Plaques are commonly seen on elbows and knees, but can affect any area including the scalp, palms, soles and genitals (5). The world wide prevalence of psoriasis is around $2 \%$ but studies in developed countries have reported higher prevalence rates of an average about $4.6 \%$,

*Corresponding Author:

\section{Kalpana Rao}

PG Scholar,

Department of Kayachikitsa,

GAMC,Mysuru.

Email: kalpana.236@gmail.com
Nearly $2 / 3^{\text {rd }}$ of people with psoriasis have a mild form of the disease, with less than $3 \%$ of the skin surface of the body affected, but others have more extensive involvement of the skin(6). Plaque psoriasis occurs worldwide, although its prevalence varies with race, geography and environmental factors(7).Inspite of various treatment modalities adopted in the contemporary medicine, owing to its recurrent nature Chronic plaque psoriasis still remains a challenge to treat. Ayurveda explains the treatment of ekakushta with the dual therapies shodhana and shamana. Bahirparimarjana chikitsa has also been explained for the treatment of twakgata vikaras (8) Various studies conducted in different centers has proven the efficacy of vamana and virechana in the management of ekakushta. Even though vamana and virechana (shodhana) effectively combats the chronic plaque psoriasis, nature of the disease is such that there is a high chance of reoccurance. Hence the disease needs to be managed with shamana aushadis after shodhana. So to disintegrate the samprapti and to increase the duration between relapse, a formulation which has not only kushtaghna effect but also works at the level of dhatwagni countering kapha and vata dosha is desirable. Hence the current study is taken up to assess and compare the clinical efficacy of kutaja siddha haritaki choorna and vyadhignadi taila with darvyadi kwatha and chitrakadi taila, after samsarjana krama of virechana in the 
management of Ekakushta vis-à-vis chronic plaque psoriasis.In the present study 20 cases of Eka-kushta visà-vis Chronic plaque psoriasis were sampled in a single group.

\section{Objectives of study}

To evaluate the efficacy of kutaja siddha haritaki choorna and vyadhignadi taila after virechana in ekakushta vis-à-vis chronic Plaque psoriasis.

\section{Materials and Methods}

Materials

The Materials used in the study were :

- Kutajasiddha Haritaki Choorna - Kutaja twak, Chitraka (root), Nimba-twak, Araghwadha (twak), Khadira (twak), Sapta Parna and Haritaki (phala) [9].

- Vyadhignadi Taila- Kushta (root), Asana(twak), Tuvaraka (beeja), Khadira (twak) and Arushkara ( phala majja)[10].

\section{Source of Drugs and Method of preparation}

- Kutajasiddha Haritaki Choorna, Vyadhignadi Taila were specifically prepared for the purpose of study and procured from SN Pandit \& Sons Pharmacy (GMP certified Unit), Shankar matt main road, Opposite to Nataraja choultry, Mysuru.

\section{Methods -Source of the data}

Subjects were selected from the OPD and IPD of Government Ayurveda Medical College \& Hospital, Mysuru and Government Hi-Tech Panchakarma Hospital, Mysuru.

\section{Sample size}

The study was completed on 20 subjects of Eka-kushta vis-à-vis Chronic Plaque Psoriasis irrespective of gender, socio-economic status and religion, fulfilling the inclusion criteria were registered for the study.The selected subject's detailed profile was prepared as per the proforma designed for the study.

\section{Sampling method}

Incidental selection and Purposive sampling technique was employed. S

\section{Study design}

It was an observational clinical study with prepost test design.

\section{Inclusion Criteria}

- Subjects with the lakshana of Ekakusta corelating with the signs and symptoms of Chronic plaque psoriasis were included

- Subjects between the age group of 18 to 60 years irrespective of gender were included.

- Subjects of Eka-kushta ,who were fit for virechana karma were only included.

- Both fresh cases and subjects who has undergone treatment earlier also were included.

\section{Exclusion Criteria:}

- Subjects with uncontrolled DM, uncontrolled HTN, Ischemic Heart Disease, Immuno compromised patients were excluded.

- Subjects suffering from any other systemic disorders which may interfere with the intervention were excluded.

- Pregnant and lactating women were excluded.

- Chronic plaque psoriasis with severe infective lesion were excluded.

\section{Diagnostic criteria}

Diagnosis was made based on the lakshana of ekakushta and signs and symptoms of Chronic plaque psoriasis. Positive Auspitz sign. Positive candle grease sign, Positive koebner phenomenon

\section{Assessment Criteria}

To assess the effect of the therapy, the Psoriasis Area and Severity Index (P.A.S.I) scoring method was adopted.

\section{Area}

For each skin section, the amount of skin involved was measured as percentage of the skin of affected part of the body and then a score from 0-6 was assigned as follows:

Table-1: Showing Diseased Skin Grading

\begin{tabular}{lc}
\hline \multicolumn{1}{c}{ Coverage } & Score \\
\hline 0 & 0 \\
$<10 \%$ & 1 \\
$10-29 \%$ & 2 \\
$30-49 \%$ & 3 \\
$50-69 \%$ & 4 \\
$70-89 \%$ & 5 \\
$90-100 \%$ & 6 \\
\hline
\end{tabular}

The severity was measured in four different Parameters - Itching ,Erythema, Scaling, Thickness

Again all these were measured separately for each skin section. These were measured on a scale of 0 4 , from none to maximum according to the following chart-

Table-2: Showing Severity Score

\begin{tabular}{lc}
\hline \multicolumn{1}{c}{ Severity } & Score \\
\hline None & 0 \\
Mild & 1 \\
Moderate & 2 \\
Severe & 3 \\
Very Severe & 4 \\
\hline
\end{tabular}

After figuring out all the scores, final "PASI" was calculated. Thus PASI scoring was calculated 
before starting the treatment, after samsarjana krama and after the completion of the Intervention and overall percentage in "P.A.S.I" scoring was calculated to assess the effect of the Intervention.

\section{Overall Assessment of Clinical Response}

- Complete Remission $-100 \%$ reduction in PASI score

- Marked improvement -75 - 99\% reduction in PASI score

- Moderate improvement $-50 \%-74 \%$ reduction in PASI score

- Mild improvement $-25-49 \%$ reduction in PASI score

\section{Assessment schedule}

- $1^{\text {st }}$ assessment was done, when Subjects reported i.e. before the treatment.

- $2^{\text {nd }}$ assessment (Pre test) was done before administering the intervention i.e. after the samsarjana krama of virechana karma (0 day)

- $3^{\text {rd }}$ assessment (Post test) assessment was done after completion of the intervention. i.e. on 20 th day.

\section{Intervention}

Before administering the intervention, all 20 subject were administered virechana karma with trivrit lehya and dose was fixed depending upon koshta of the patients, Samsarjana krama was carried out depending upon the koshta shuddhi. From the next day of Samsarjana karma, Kutaja siddha haritaki choorna 12 gms in three equally divided doses, thrice daily with madhu as anupana after food and Vyadhignadi taila for external application twice daily, was given for continuous 20 days

\section{Statistical methods}

- The results were compared and analysed by using following statistical methods.

- Descriptive statistics

- Chi-square test.

\section{Observations and Results}

In the present study among 20 subjects who completed the clinical trial, a maximum of 7 subjects belonged to the age group of $51-60$ years, 5 belonged to the age group of 31-40 years, 4 belonged to the age group less than 30 years and 4 belonged to age group of 41-50 years. Among the 20 subjects, 11 were male and 9 were female. The observation regarding the socio economic status of the individual subjects in this study, showed that 9 of them belonged to Lower middle class, 8 belonged to below poverty line , 3 belonged to upper middle class. The observation regarding the food habits of the subjects in this study showed that majority of them i.e.16 belonged to Mixed food habits (veg \& nonveg) and 4 belonged to vegetarian food pattern. In the Present study, it was observed that maximum subjects i.e. 14 were from Rural locality and 6 belonged to Urban locality. And observation based on family history of Eka Kushta vis-a-vis Chronic Plaque Psoriasis, was present in only one subject and absent in 19 subjects. The observation regarding the mode of onset of Eka Kushta in subjects in this study showed that all 20 subjects had gradual onset. In this study, 7 subjects approached the hospital for the first time to take treatment and 13 had already taken different forms of treatment of varying duration. Among 20 subjects, 3 had chronicity of less than year, 12 with chronicity of 1 5 years, 5 with chronicity of 6-10 years. Among 20 subjects, 2 presented with site of onset on Scalp, 3on Elbows, 0 on abdomen, 1 on Knee, 4 patient on back, 0 on palm and 10 on leg. Among 20 subjects, all 20 reported with worsening of symptoms in winter season.

\section{Discussion and results}

\section{Total PASI of Head Region}

In single Group for all 20 subjects mean was 2.5350 with SD of 6.26656 before treatment, 0.9100 with SD of 2.10711 after samsarjana krama (pre test) and 0.0600 with SD of 0.22572 after Intervention (post test). Thus the result of Total PASI of Head Region is statistically highly significant.

Table no-03 Showing Total PASI of Head region

\begin{tabular}{|l|c|c|c|}
\hline & Mean & Std. Deviation & N \\
\hline PASI_head_BT & 2.5350 & 6.26656 & 20 \\
\hline PASI_head_AS & 0.9100 & 2.10711 & 20 \\
\hline PASI head_AT & 0.0600 & 0.22572 & 20 \\
\hline
\end{tabular}

\begin{tabular}{|c|c|c|c|c|c|}
\hline Source & Type III Sum of Squares & Df & Mean Square & F & Sig. \\
\hline Change & 64.249 & 2 & 32.124 & 6.027 & 0.004 \\
\hline Change* Grp & 10.450 & 2 & 5.225 & 0.980 & 0.380 \\
\hline
\end{tabular}

Total PASI of Upper Extremities : For all 20 subjects mean was 6.9700 with SD of 5.15824 before treatment, 3.0500 with SD of 3.06826 after samsarjana karma (pre test) and 0.7100 with SD of 1.10401 after Intervention (post test). Thus the result of Total PASI of Upper Extremities is statistically highly significant for all 20 subjects. 
Table no-04 Showing Total PASI of Upper Extremities

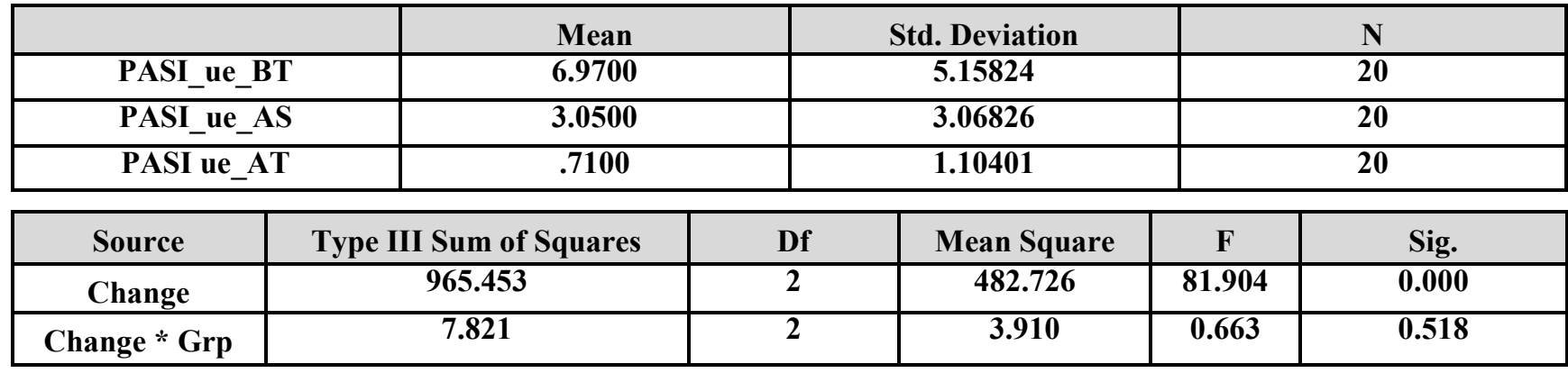

\section{Total PASI of Trunk}

The mean was 10.9450 with SD of 6.73197 Before Treatment, 4.5850 with SD of 3.33818 After samasarjana krama (pre test) and 0.7600 with SD of 1.23731 After Intervention (post test) for all 20 subjects. Thus the result of Total PASI of Trunk is statistically highly significant.

Table No-05 Showing Total PASI of Trunk

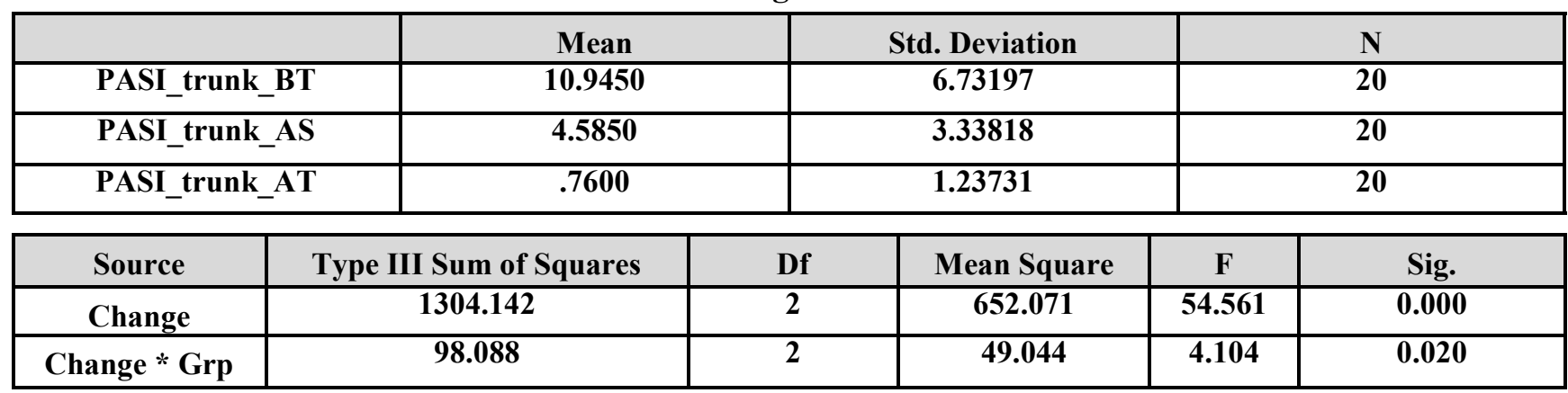

\section{Total PASI of Lower Extremities}

The mean was 17.9500 with SD of 14.02102 Before Treatment, 8.4100 with SD of 7.91653 After Samsarjana Krama (pre test) and 1.2900 with SD of 2.18365 After Intervention(post test) for all 20 subjects. Thus the result of Total PASI of lower Extremities is statistically highly significant.

Table No-06 Showing Total PASI of Lower Extremities

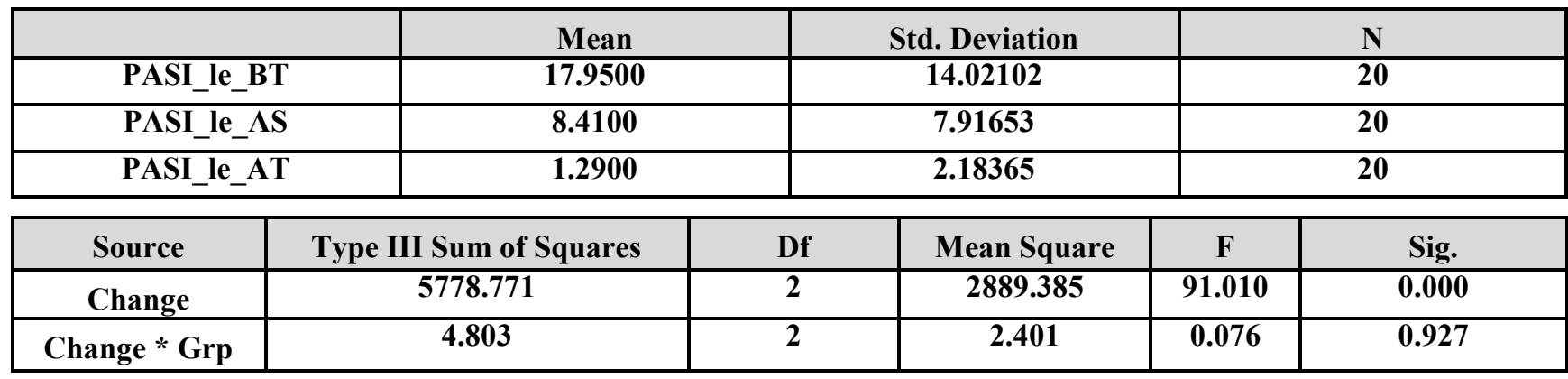

The overall result of the study revealed that all 20 subjects has Statistically significant results i.e. out of 20 subjects $3(15 \%)$ got complete relief, $10(50 \%)$ got marked relief and $7(35 \%)$ had moderate relief . The effect of intervention on Itching, Erythema, Scaling, Thickness, Area was statistically significant in all the areas for all 20 subjects.

By this we can infer that, shamanoushadhis i.e. Kutaja siddha haritaki choorna and Vyadhignadi taila has good result in the management of ekakushta vis-à-vis chronic plaque psoriasis.

Table No-07 Showing Overall Assessment of PASI in Percentage

\begin{tabular}{|c|l|l|l|}
\hline \multirow{3}{*}{ Overall } & Complete (100\%) & 3 & $\mathbf{1 5 . 0 \%}$ \\
\cline { 2 - 4 } & Marked (75-99\%) & 10 & $\mathbf{5 0 . 0 \%}$ \\
\cline { 2 - 4 } & Moderate (50-74\%) & 7 & $\mathbf{3 5 . 0 \%}$ \\
\hline \multirow{2}{*}{ Total } & Total & $\mathbf{2 0}$ & $\mathbf{1 0 0 . 0 \%}$ \\
\hline
\end{tabular}




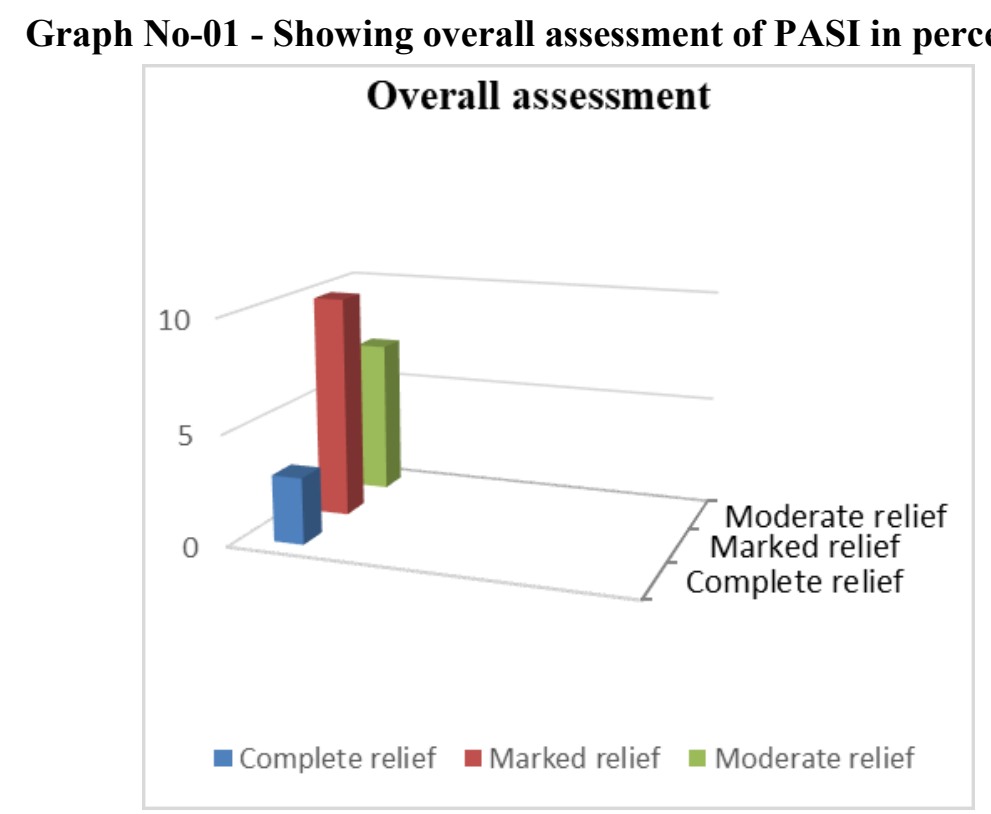

Fig 1: Before treatment

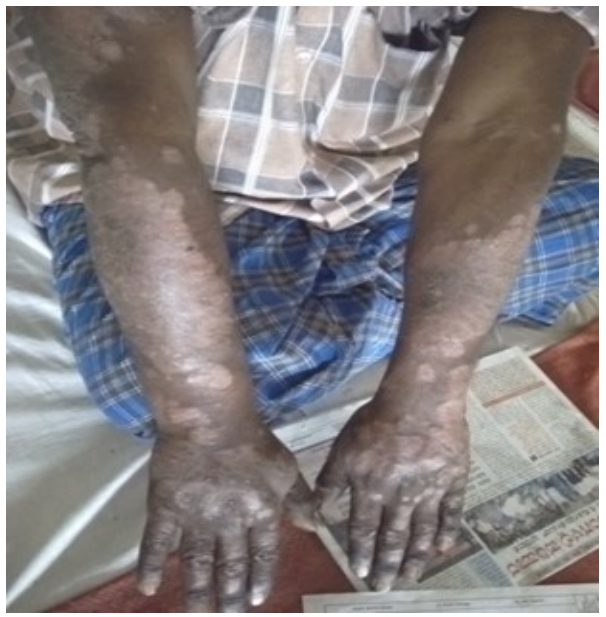

Probable mode of action of Kutaja Siddha Haritaki

\section{Choorna}

\section{Action on Dosha}

Kutajasiddha haritaki choorna acts as tridoshahara

By the effect of tikta and kashaya rasa of all the drugs, the pitta dosha is pacified and due to the ushna veerya vata kapha dosha is pacified, it acts as kanduhara raktashodhaka by acting on reduction of vitiated kaphadosha

It is kushtaghna by the effect (prabhava) of drugs like Khadira, Kutaja,Saptaparna and Aragwadha.

\section{Action on Dhatu}

Kutaja siddha haritaki choorna has tikta and kashaya rasa, these two rasa by the virtue of their pharmacological properties causes Tvak, mamsa sthirikarana (nourishment and strengthening of skin and muscle) It also does Vishaghnata (removes toxins), Kledaupashosana and ropana (induces the healing process).

By the Samsrana karma of Araghwadha there will be shodhana of vitiated dosha.
Fig 2: After treatment

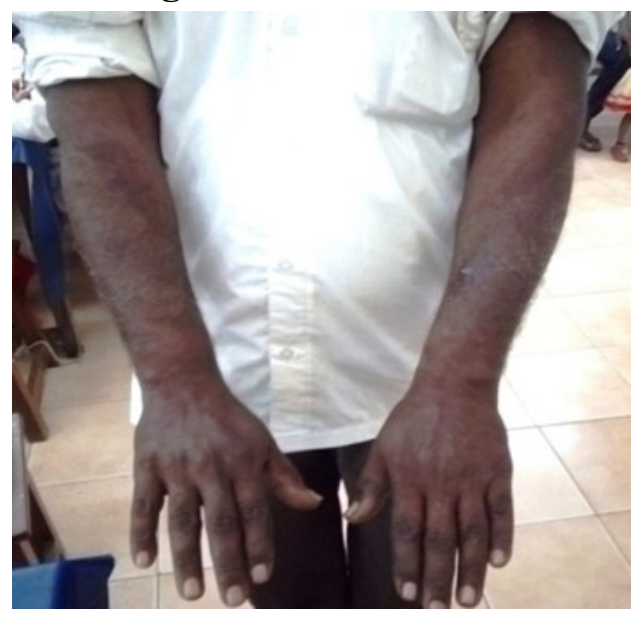

Pharmacological researches on few drugs like Haritaki, Nimba and Saptaparna have shown that these ingredients acts at the skin level and helps the skin to become healthy. Viz; Haritaki exhibited potent improvement of erythema and scaling scores, decrease of epidermal, ear and skin-fold thickening, decrease of tumor necrosis factor $\alpha(\mathrm{TNF} \alpha)$, interleukin (IL)-17A, IL-23 and matrix metalloproteinase (MMP)-9 expression and decrease of keratinocyte proliferation. [11]

Nimba shows therapeutic role in enhancement of antioxidant activity, inhibition of bacterial growth, and modulation of genetic pathways. Nimba plays role as free radical scavenging properties due to rich source of antioxidant. Nimba also plays role as anti-inflammatory via regulation of pro inflammatory enzyme activities including cyclo oxygenase (COX), and lipoxygenase (LOX) enzyme.[12]

Saptaparna (Alstonia scholaris)-inhibits all inflammatory activity in human keratinocyte cell, it decreases skin irritation and increasing the anti-aging function.[13] 


\section{Probable mode of action of Vyadhignadi Taila} Action on Dosha

Vyadhignadi taila pacifies kapha due to its katu rasa, laghu, ruksha and teekshna guna, as it possess ushna veerya it pacifies both vata and kapha. Pitta shamana takes place due to tikta and kashaya rasa.

\section{Action on Dhatu}

The dravyas with Tikta rasa causes shtireekarana of mamsa and twacha, also does twak prasadana and rakta vishodhana and so becomes twachya and varnya. Its deepana property enhances the agni at twacha level by acting on bhrajaka pitta and may help in reducing the Krishna aruna varna of twacha.

Kushthagna property of drugs like Asana[14] Bhallataka[15], Tuvaraka[16] directly helps in vyadhi pratyanika chikitsa. Asana is established to have pharmacological activity as it inhibits T-cell proliferation[17]. Bhallataka has immuno modulatory effect and anti-inflammatory effect. S.anacardium has alfatoxin B1 and mono hydroxy phenols which has effective dermatological response[18]

Krimighna property of the drug may prevent secondary infection as well as help in reducing the lesions.

Kushta (S.lappa) decreases immunoglobulin E, cytokines and chemokines with reduction in histopathological features of psoriasis[19].

Thus combined effect of all the drugs of vyadhighnadi taila contributed in normalising the skin. The taila also acts by keratinocyte proliferation inhibition, retarding the cell division to $90 \%$ level.

\section{Conclusion}

On the basis of the conceptual analysis and observations made in the present study, the following conclusions were drawn.

Eka-kushta is a vata kaphaja rakta pradoshaka vyadhi and one among the kshudra kushta and it bears a greater resemblance with chronic plaque psoriasis.

Symptoms like Matsyashakalopamam, Krishna aruna mandala, mahavastu and Abhrakapatra sadrusha lesions are the cardinal features of eka-kushta and they are similar to that of plaque psoriasis.

An observational clinical study was conducted on 20 subjects, who was assigned in a single Group were treated with Kutaja siddha haritaki choorna internally and Vydhignadi taila for external application, for consecutive 20 days. Intervention was started after samsarjana krama of virechana.

In single Group with 20 subjects PASI score was reduced remarkably and showed clinically significant result in reduction of all the symptoms. The Overall assessment showed complete relief in 3 subjects, 10 subjects got marked relief and 7 subjects got moderate relief.

Hence this study showed that kutajasiddha haritaki choorna and vyadhignadi taila has good result in the management of Eka-kushta vis -a -vis Chronic plaque psoriasis.

\section{Reference}

1. Agnivesha,28/11Sutrasthana:vaidyaJadavjiTrikamjiAc harya(ed), charaka samhita,Ayurveda Dipika commentary.chakrapanidatta. , repeat edition,Varanasi, Chaukhamba subharati prakashan 2005,P-179

2. Agnivesha,7/29\&31Chikitsasthana.Vaidya:JadavjiTrik amjiAcharya(ed)

Charaksamhita,AyurvedaDipika,commentary,Chakara panidatta,repeat edition , Varanasi,Chaukhamba subharati prakashan,, 2005.P-451

3. Agnivesha,7/21 chikitsasthana,Vaidya Jadavji Trikamji Acharya(ed) charaka samhita,Ayurveda Dipika commentary, Chakrapanidatta, repeat edition,Varanasi,Chaukhamba subhaarati prakashan,2005, P-451

4. Harrisons principles of internal medicine, section 9,52 chapter,Ed -Dennis .L.Kasper,Mcgraw hill,ed $18^{\text {th }}$, library of congress cataloging in publication Data2005. P-395

5. www.wikipedia.org.psoriasis 26/5/2018 12:57

6. apps.who.int/gb/ebwha/pdf_files/EB133/B133_5en.pdf 26/5/2018 13:02

7. http://emedicine.medscape.com/article/1108072overview\#a5 26/5/2018 13:04

8. Agnivesha, Charaka samhita Ayurveda Dipika Commentary of Chakrapanidatta, revised by Charaka and Dridabala, Ed by Vaidya jadavji Trikamji Acharya, Chaukhamba Subharati Prakashan, Varanasi, repeat edition, 2005, Sutrasthana 11/55, P-78

9. Vagbhata, Astanga Hridayam, Sarvanga sundara commentary of Arunadatta and commentary of Ayurveda rasayana of Hemadri by Dr.Anna Moreswar kunte and Krsna Ramchandra Sastri Navre,Ed by Pt.Hari Sadsiva Sastri Paradakara, Chaukhamba Sanskrit Prathisthan, Varanasi, reprint $6^{\text {th }}$ edition, chikitsa sthanam, 19/37 P-714

10. Sahasra Yogam, taila yogas,pancham prakaranm, Ed. By vaidya mahendrapal singh arya sanskrit-hindi translation by Dr.D.V. pandit rao, kendriya ayurved evam siddha anusandhana parishad,new delhi,30 nov 1990,yoga no 116 P-290

11. https://www.ncbi.nlm.nih.gov/pubmed/27383847 4/3/18 7:13

12. https://www.ncbi.nlm.nih.gov/pmc/articles/ PMC4791507/4/3/18 7:25

13. http://dx.doi.org/10.1155/2012/190370 4/3/18 7:00

14. The ayurvedic pharmacopia of India, New delhi:Government of India ministry of Ayush. 1st ed. pharmacopoeia commission for indian medicine \& homoeopathy ghaziabad;2016, Part 1, vol 1,P- 15

15. Dravyaguna Vijnana by Dr.JLN Shastry, Published by Chaukhamba Orientalia,Varanasi,2 ${ }^{\text {nd }}$ Edition2005,volume $2^{\text {nd }}$, Page - 135-138.

16. Dravyaguna Vijnana by Dr.JLN Shastry, Published by Chaukhamba Orientalia,Varanasi, $2^{\text {nd }}$ Edition2005,volume $2^{\text {nd }}$, Page - 64-66.

17. www.wjpr.net/download/article/1422699052.pdf 4/3/18 7:45

18. https://www.ncbi.nlm.nih.gov/pubmed/11411037 4/3/18 8:30

19. https://www.ncbi.nlm.nih.gov/pmc/articles/ PMC4588719/26/5/2018 13:11. 